\title{
BARSHA'SHA: A REVIEW ON FAST ACTING UNANI COMPOUND FORMULATION
}

\author{
Mohd. Afsahul Kalam ${ }^{1}$, Zaffar Hussain ${ }^{2}$, Mohd Musaib Bhat ${ }^{3}$ and Mohd Naved $^{3}$ \\ ${ }^{1}$ Research Officer Unani and Lecturer Department of Ilmul Advia \\ Regional Research Institute of Unani Medicine, Kashmir University, Srinagar-190006. \\ ${ }^{2}$ Professor, Department of Moalajat \\ Regional Research Institute of Unani Medicine, Kashmir University, Srinagar-190006. \\ ${ }^{3}$ PG Scholars, Department of Ilmul Advia \\ Regional Research Institute of Unani Medicine, Kashmir University, Srinagar, 190006.
}

\section{Review Paper}

Received: 12.10.2021

Revised: 22.10.2021

Accepted: 10.11.2021

\begin{abstract}
Various compound formulations of Unani System of Medicine are used for the treatment of several ailments by boosting immune system and improving functioning of vital organs. Barsha'sha is a classical Unani formulation which is composed of Papaver somniferum, Hyoscyamus niger, Crocus sativus, Euphorbia resinifera, Piper nigrum, Valeriana officinalis, Anacyclus pyrethrum and honey. It is famous for its quick action and used for the treatment of CNS, hepatic, cardiac, sexual and digestive disorders. Due to its quick action to resolve the Ailments, it is named as Barsha'sha which means instant relief. The present review is not only focused on the classical uses of the compound but also presents a detailed account of its method of preparation, nature of ingredients present in it, with their medicinal importance and pharmacological studies.
\end{abstract}

No. of Pages: $5 \quad$ No. of Tables: 01

References: 28

Keywords: Barsha'sha, Antidote, Classical formulation, Unani System of Medicine.

\section{INTRODUCTION}

Barsha'sha is one of the oldest efficacious preparations in Unani System of Medicine, and due to enormous benefits, it has created its own niche in Unani pharmacotherapy. It is also known as "Majun Barsh" and "Dawa al-Sha'ir". It is one of the emergency drugs of Unani Medicine which is known for its quick action. Barsha'sha is an Aramaic word which is known as Bara al-Sa'ain Arabic which is a compound word comprising of two words Viz "Bara” and" Sa 'a” means "Quick relief ${ }^{12,}$. There are various formulations known by this name with some modifications, done by Ibn Sina, Dawood Antaki, Ibn Jazla, Amaduddin Mahmood Shirazi, Mahmood bin Iliyas Shirazi and Habbatulla Abu Barkati.
Most of the physicians accept that it was first prepared by ancient Greeks and with some modification it was again prepared by Jalinus.Ibn Sina has prepared Barshasha by doing some modification in the formulation of Afluniya Rumi $^{2}$. It has survived a long history due to its spectra of medical benefits. It gives extraordinary results at even very low doses. There is no doubt that due to its choicest ingredients, it has potency to act as a good antidote, therefore it is necessary that we explore its ingredients in detail.

\section{METHODOLOGY}

Relevant literature regarding Barshasha was retrieved from Classical Unani Books, like Al-Qarabadeen, Bayaz-i-Kabir,

*Corresponding author: afsahnium@gmail.com 
Ghina Muna and databases like Web of Science, Google Scholar, Baidu Scholar, Springer, PubMed, Sci Finder, and Science Direct was also searched for the various ingredients present in the compound.

\section{INDICATIONS OF BARSHA'SHA}

Since ancient times, Barsha'sha has been used effectively to treat cold, catarrh, coryza, chronic and acute cough. Due to its Mumsik effect, it has been used to treat Du'f-i-bah (loss of libido) and Sur't-i-Inzal (premature ejaculation). It is very effective to treat Amraz-i-Sawdawiyya and Balghamiyya such as Hiziyan (delirium), Malikhuliya (melancholia), Falij (paralysis), Du'f-i-A'sab (nerve weakness), Laqwa (Bell 's palsy), Ra'sha (tremors), Sara'(epilepsy), Sahr (Insomnia),
Nasiyan (dementias), Dawar (vertigo), Tinin (tinnitus) etc. ${ }^{1}$ It is also indicated for restoring integrity of gums, cures Ganda Dahani (halitosis), Sailan-i-lu'ab-i-Dahan (excessive salivation), Jarayan-i-Khoon (hemorrhage), Waja' al-mi'da (abdominal pain), Sudda-i-Jigar (obstructive diseases of liver), Du'f-i-jigar (hepatargia) and chronic fevers. It is indeed one of the wonderful multipotent drugs in Unani System of Medicine. Even, it works as an antidote for many poisons ${ }^{1,}{ }^{3}$. If Zusantariya Mi'wi (erosive enteritis) become severe due to spasmodic pain, Barsha'sha can be given per orally to induce Mukhaddir (local anesthetic effect) on intestine. ${ }^{4}$

INGREDIENTS OF COMPOUND: The ingredients of this compound areas follows ${ }^{3}$
a. Afiyun Khalis (Papaver somniferum)
b. Bazrulbanj (Hyoscyamus niger)
c. Filfil Seyah (Piper nigrum)
d. Filfil Safed (Pipernigrum)
e. Zafran (Crocus sativus)
f. Sumbuluttib (Valeriana officinalis)
g. Aqer Qerha (Anacyclus pyrethrum)
h. Farfiyun (Euphorbia resinifera)
I. Honey

\author{
$2 \frac{1}{2}$ Tola (30gm) \\ each 5 Tola (60gm) \\ 1 1/4 Tola (15gm) \\ each $3 \mathrm{gm}$
}

3 times more than the weight of all the drugs combined.

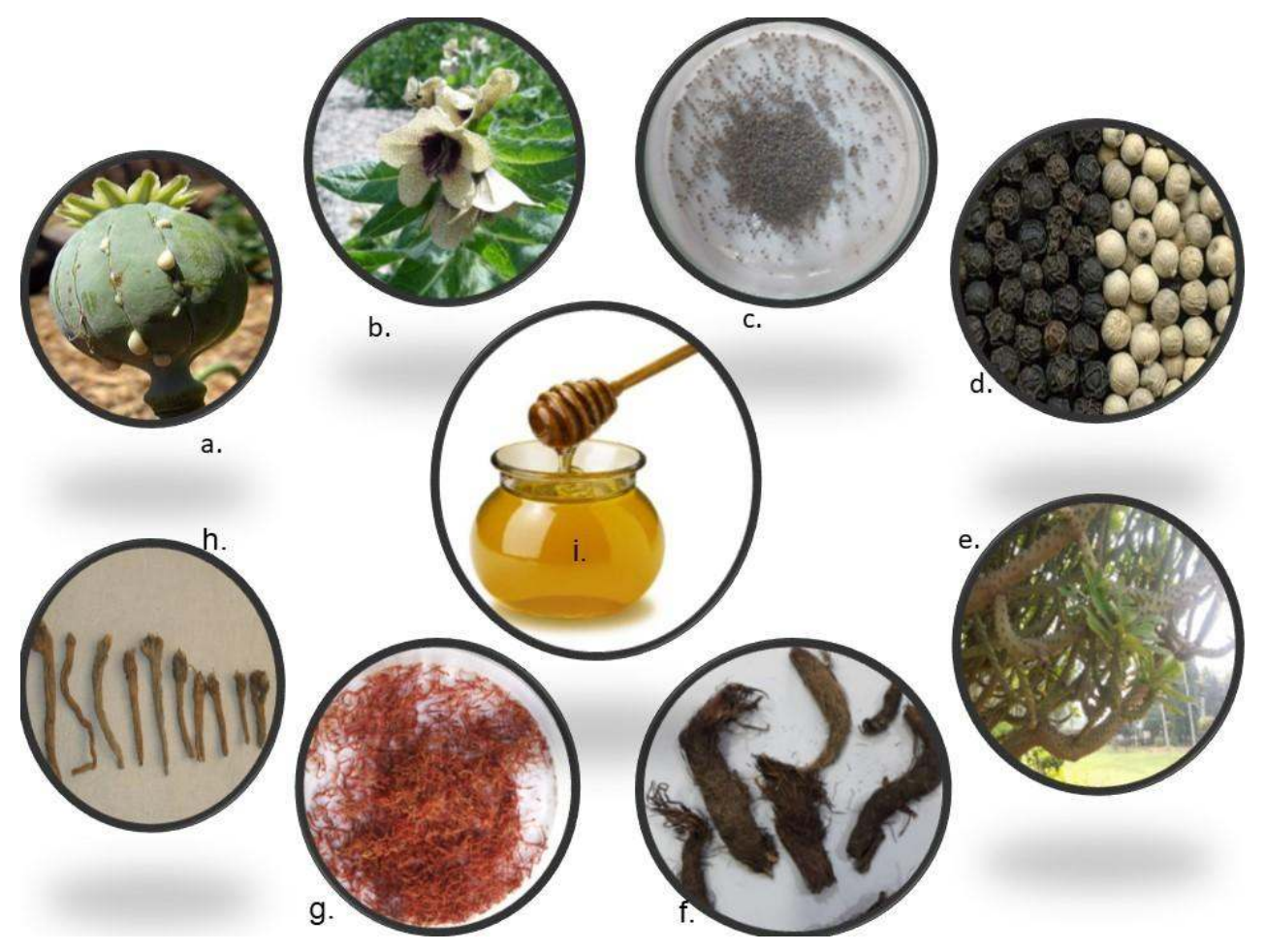

Fig.: Showing a. Afiyun (exudate on fruit), b,c. Ajwain Khurasani (plant with flower and seeds), d. Filfil Seyah (fruit), e. Farfiyun (plant), f. Sumbuluttib (root and rhizome), g. Zafran (stigma), h. Aqer Qerha (root) and i. honey. 


\section{METHOD OF PREPARATION}

Grind these single drugs individually, powder them and sieve them together. Dissolve Zafran separately in Arq-i-Gulab and mix all drugs with honey three time the weight of all the drugs combined. After mixing, bury this preparation in barley (Sha'ir) for three months that is why it is also called "Dawa alSha'ir". Then after three months when its temperament reaches a permanent disposition, it can be used for medicinal purposes $^{2,3}$.

Shelf life: Its strength and potency lasts five years ${ }^{3}$

\section{DOSAGE AND MODE OF ADMINISTRATION}

Its dosage ranges from 4 Rati to 2 Masha (Ratti=125mg; Masha=gm) and it gives best results when taken with Arq Gaozaban 12 Tolas $(120 \mathrm{ml})$ or water $^{3}$. As per new recommendations dosage of 1 Rati $(125 \mathrm{mg})$ is safe and effective.

\section{DETAIL OF INGREDIENTS}

Afiyun (Papaver somniferum L.): Afiyun consists of the resinous exudate from the capsule of Papaver somniferum of Papvaraceae family. Its temperament is cold and dry in $4^{\text {th }}$ degree. Due to its anesthetic, analgesic and desiccant properties, it is beneficial in inflammatory conditions of nasal mucosa. It has been effectively used as an analgesic to relieve headaches, trigeminal neuralgia, pleural pain, backache, sciatica, arthritis, toothache, earache, ocular pains and it has been used for other kinds of pains as well, locally and as a liniment. Due to its hypnotic property, it is used in insomnias, bilious, melancholic, sanguine meningitis etc. it is also used in visceral pain. It also has aphrodisiac property. Its correctives are Filfil Seyah and saffron ${ }^{5,6,7}$. The extract of seeds showed highly significant anti-secretory (antidiarrhealactivity) against $E$. coli enterotoxin-induced secretory responses in experimental animals. ${ }^{8}$

Bazrulbanj (Hyoscyamus niger L.): Its name is Ajwain Khurasani, it is obtained from the seeds of its Hyoscyamus niger of Solanaceae family. Its temperament is cold and dry in $3^{\text {rd }}$ degree. It is beneficial in cough (Su'al) due to its anesthetic and relieving action. Along with Opium it induces sleep and gives relief in toothache. It is a toxic drug and is used after detoxification. Its side effects are though countered by Filfilain and honey is also used as corrective $\mathrm{e}^{5,6,7}$.

Filfil Seyah and Safed (Piper nigrum L.): Filfil Seyah is a fruit obtained from Piper nigrum L. of Piperaceae family. The temperament of Filfil Seya his hot and dry in $3^{\text {rd }}$ degree, it smells good, tastes bitter and causes lot of salivation on chewing. It is useful in dementia, paralysis, nerve pain. When taken orally it strengthens stomach, acts as liver tonic and maintains good eyesight. It acts as carminative, and expels phlegm from the lungs. It has aphrodisiac effect and as antidote it counters the harmful effects of cold poisons like opium and Hyoscyamus niger. It is harmful for people of hot temperament. Honey is added as corrective $e^{5,6,9}$.

Filfil Safed is less potent as compared to Filfil Seyah but it increases the antidote potency of Filfil Seyah when taken together.

Zafran (Crocus sativus L.): It is also known Kesar obtained from the stigma of the saffron flowers (Crocus sativus L.) of Iridaceae family. It is fragrant and acrid, yet good in taste. Its temperament is hot in $2^{\text {nd }}$ dry in $1^{\text {st }}$ degree ${ }^{10}$. Due to its Mufarrih (exhilarant), Qabid (astringent), Muhallil (resolvent) and Jali (detergent) actions, it is useful in heart, brain and liver diseases. It is general body tonic and aphrodisiac. It helps respiratory organs and helps in difficulty in breathing, painful labor; where 4gm saffron orally is used to make delivery quick and easy. It also has tranquilizing properties on heart and brain. It causes diuresis by stimulating kidneys and ureters. In excessive use it causes headache and harmful for lung and stomach which is countered by Usara Zarishk with Jawarish Safarjali, ${ }^{5,6,10}$. Different pharmacological studies done for various activities related to nerve and cardiac disorders such asaphrodisiac ${ }^{11}$, anticonvulsant ${ }^{12}$, antioxidant ${ }^{13}$, anxiolytic ${ }^{14}$, antidiabetic, dyslipidemic ${ }^{15}$, anti-inflammatory, analgesic ${ }^{16}$, antidepressant ${ }^{17,18}$.

Sumbuluttib (Valeriana officinalis L.): Sumbuluttib is the roots obtained from Valeriana officinalis of Valerianaceae family. Its temperament is hot in $1^{\text {st }}$ and dry in $2^{\text {nd }}$ degree.It is very beneficial for the vital organs in cold diseases and one of the important drug for liver and nerve diseases. It has carminative property and is useful in obesity, jaundice and inflammatory conditions of stomach, liver, ureters, uterus etc. Various pharmacological studied proves its efficacy in neurological disorders. Veith et al., (1986) has investigated the effect of its whole herb extract, valarianic acid and valerenal given i.p. in mice and found to produce significant sedation, ataxia and anticonvulsant effects ${ }^{19}$. Petkov (1979) reported that valepotriates an important component of Valerian, prevents the appearance of acute coronary insufficiency as well as vasopressin-induced arrhythmia, provoked a short-lived increase of coronary blood flow, and had moderate positive inotropic and negative chronotropic effects. ${ }^{20}$ A significant increase in coronary blood flow, a transient fall in blood pressure and a decrease in heart rate was noticed when cats were intravenously injected with valerian extracts ${ }^{21}$. Circosta et al. (2007) has reported significant anti-coronaryspastic, anti-bronchospastic, and anti-hypertensive activities from ethanolic and aqueous extracts of $V$. officinalis L. roots in anaesthetized guinea-pigs and were found similar to those exhibited by nifedipine ${ }^{22}$. 
Aqer Qerha (Anacyclus pyrethrum DC.): Aqer Qerha is the root obtained from Anacyclus pyrethrum of Asteraceae family. Its temperament is hot and dry in $3^{\text {rd }}$ degree $^{23}$. It is eliminant of the morbid humors in brain, expectorant and calorific. It is therefore used in diseases of cold temperament like facial, paralysis, hemiparesis, tremor, tetany, epilepsy etc. with honey it is used to cure epilepsy 5,6,24. Anticonvulsant activity of its hydro alcoholic extract on Maximal Electric Shock and Pentylenetetrazole induced convulsion on animal model was done by Kalam et al. (2015) ${ }^{25}$. It is injurious to lungs but it is used in small quantity in this preparation. The various extracts of the plant root is also reported for various pharmacological activities like antidepressant ${ }^{26}$, anti-inflammatory ${ }^{27}$, immune-stimulating ${ }^{28}$, activities in animal models.

Farfiyun (Euphorbia resinifera): Farfiyun is the secretion obtained from the scratching on the branches of Euphorbia resinifera with a sharp object. It belongs to the family Euphorbiaceae. Its temperament is hot and dry in $4^{\text {th }}$ degree.It is an effective drug for cold diseases like Falij (paralysis), Laqwa (facial palsy), Ra'sha (tremor), Khadar (numbness), Sar' (epilepsy), Qulanj (colitis),Waja'al-Mafasil (arthritis) and ascites ${ }^{6}$.It is injurious to intestines and uterus but its concentration in the preparation is very low to produce any serious effects.

Asal (honey): Asal (honey) is a semi liquid animal origin drug which is collected from the hives of Apismellifera (honey bee). It is hot and dry in $2^{\text {nd }}$ degree. It hasJali (detergent), Mufattih Sudad (deobstruent), Muhallil (antiinflammatory), Dafi' Ta'affun (antimicrobial), Mudir (diuretic) activities and used for the treatment of inflammation of throat, tongue, palate and uvula. It is an antidote of mushroom poisoning ${ }^{6,24}$.

In this formulation honey is used as a vehicle and also for countering the toxic effect of other ingredients of the compound. Due to its preservative property it also prolongs the life span of the compound.

\section{DISCUSSIONAND CONCLUSION}

Barsha'sha is a classical formulation of Unani Medicine which is known for its fast acting properties, and used for the treatment of various neurological and other disorders which have challenged human being for long like, epilepsy, paralysis, melancholia, trigeminal neuralgia, amnesia, dementia, vertigo etc. When this multipotent preparation (Barsha'sha) is prepared, due to temperamental antagonism in its constituents, it should be, therefore as its inventor has recommended to dump it in heap of barley and wheat for 3 months so that its temperament reaches a permanent disposition. Its dosage has been determined accurately as per the time, but due to toxicity studies and safety evaluation and with progressive decline in immune status of populations, its dosage has been reframed now. This transition in dosage has been considered by documenting long term side effects of its ingredients. This can also be understood from analogy of a running bicycle, if all brakes are applied at once, it may overturn, therefore for safety we need to apply brakes slowly, similarly in order to counter illnesses using Barshasha we need to understand the adverse effects it may bring forth, therefore lowering the dosage and increasing the time of regimen is an effective way to not only treat the disease but minimize the adverse effects, if any. Since the Barsha'sha nowadays is not prepared using classical method of dumping in barley and wheat, so its efficacy is not up to mark, Therefore it is necessary that the methodology of its preparation is reconsidered. However as of now no any pharmacological study has been done on Barsha'sha, but since time immemorial the drug was tested by various physicians and found effective in various acute and chronic conditions as mentioned in classical literatures. So proper pharmacological studies are required for its efficacy in acute diseases and safety as well.

\section{ACKNOWLEDGEMENT}

Being an author for correspondence of this review paper, first I thank to our Assistant Director, In Charge, RRIUM, Srinagar for providing facilities in the institute. In addition to this I am highly thankful to all the authors/editors of the books from where the material for this paper was consulted, discussed and used herein.

\section{REFERENCES}

1. Anonymous. Al-Qarabadeen. Central Council for Research in Unani Medicine, New Delhi. 2006; 40.

2. Iqbal Ahmad Q. Dastur al-Murakkabat. International Printing Press, Aligarh. 2012; 52, 53

3. Kabiruddin H. Bayaz-i-Kabir. Idara Kitabus Shifa, New Delhi. 2010.

4. Ibn Hubal Baghdadi. Kitb l-MukhtartFi'lTib: Vol-3. Central Council for Research in Unani Medicine, New Delhi, 2004, 238-242.

5. Kabiruddin MH. Makhzanul Mufradat. Aijaz Publishing House, New Delhi, 2014.

6. Ghani Najmul. Khazainul Advia. Idara Kitab al-Shifa, New Delhi, 2011.

7. Ibn Baitar. Al-Jami Li Mufridat Al-Advia wa AlAghzia, Vol-1 (Urdu Trans: Central Council for Research in Unani Medicine), Department of AYUSH, Ministry of Health and Family Welfare, Govt. of India, New Delhi, India. 1985; 104, 293-297.

8. Khare CP. Indian Medicinal Plants. An Illustrated Dictionary. Springer Science+Business Media, LLC. 2007. 
9. Qamri MBN. Ghina Muna. Central Council for Research in Unani Medicine, New Delhi. 2008; 11, 17, 31.

10. Ibn Baitar. Al-Jami Li Mufridat Al-Advia wa Al-Aghzia, Vol-2 (Urdu Trans: Central Council for Research in Unani Medicine), Department of AYUSH, Ministry of Health and Family Welfare, Govt. of India, New Delhi, India. 1986; 339.

11. Akhondzadeh BA, Khondzadeh S, Ghoreishi S, Noorbala A, Rezazadeh S. Petal and Stigma of Crocus sativus L. in the Treatment of Depression: A Pilot Double-Blind Randomized Trial. J. Med. Plant. Res. 2008; 7: 29-36. 48.

12. HosseinzadehH and Talebzadeh F. Anticonvulsant evaluation of saffranal and crocin from Crocus sativus in mice. Fitoterapia, 2005; 76: 722-24.

13. Hosseinzadeh $\mathbf{H}$, Molaei $M$, Shakeri $M$, Rajabi O, Shamsa A. Evaluation of Crocus sativus L. (saffron) on male erectile dysfunction: A pilot study. Phytomedicine 2009, 16, 690-693.

14. Pitsikas N, Boultadakis A, Gergiadou G, Trantilis PA, Sakellaridis N. effect of the active constituents of C sativus L. in an Animal model of anxiety, Phytomedicine. 2008; 15: 1135-39.

15. Eghdami K, Erfanparast A, Farshid AA, Samadi F, Tamaddonfard E. Comparison of the effects of crocin, safranal and diclofenac on local inflammation and inflammatory pain responses induced by carrageenan in rats. Pharmacol. Rep. 2013, 65, 1272-1280.

16. Tamaddonfard E, Erfanparast A, Farshid AA, Imani M, Mirzakhani N, Salighedar R, Tamaddonfard S. Safranal, a constituent of saffron, exerts gastro-protective effects against indomethacininduced gastric ulcer. Life Sci. 2019, 224, 88-94.

17. Murray CJ and Lopez AD. Alternative projections of mortality and disability by cause 1990-2020: Global burden of disease study. Lancet 1997, 24, 1498-1504. 45.

18. Khazdair MR, Anaeigoudari A, Hashemzehi M, Mohebbati R. Neuroprotective potency of some spice herbs, a literature review. J. Tradit. Complement. Med. 2018, 9, 98-105.
19. Veith J, Schneider G, Lemmer B, Willems M. The effect of degradation products of valepotriates on the motor activity of light-dark synchronized mice. Planta Med. 1986; 3:179-183.

20. Petkov V. Plants and hypotensive, anti-atheromatous and coronarodilatating action. Am. J. Chin. Med. 1979; 7: 197-236.

21. Zhang BH, Meng HP, Wang T. et al. Effects of Valeriana officinalis L. extract on cardiovascular system. Yao Hsueh HsuehPao 1982; 17: 382-384.

22. Circosta C, Pasquale RD, Samperi S, Pino A, Occhiuto F. Biological and analytical characterization of two extracts from Valeriana officinalis. J. of Ethnopharmacol. 2007; 112: 361-367.

23. Kalam MA, Karim MS, Anzar A, Sofi G, Ghufran A and Shahzad A. Aqer Qerha (Anacyclus pyrethrum DC.) A Nobel drug of Unani System of Medicine-a review. Ijp, 2015; 2(3): 116-122.

24. Ibn Baitar. Al-Jami Li Mufridat Al-Advia wa AlAghzia, Vol-3 (Urdu Trans: Central Council for Research in Unani Medicine), Department of AYUSH, Ministry of Health and Family Welfare, Govt. of India, New Delhi, India. 1999; 256.

25. Kalam MA, Shafat Karim, Ghulamuddin Sofi and Ghufran Ahmad. Evaluation of Anticonvulsant Activity of Aqer Qerha (Anacyclus pyrethrum DC.) Root in Experimental Animals. Hippocratic Journal of Unani Medicine. 2015; 10 (4): 1-12.

26. Badhe SR, Badhe RV, Ghaisas MM, Chopade VV, Deshpande AD. Evaluations of antidepressant activity of Anacyclus pyrethrum root extract. 2010: Vol 4 (2), 7982. 39.

27. Victor R, Esther R, Salvador C, Joseplglesias. Antiinflamatory activity of some extracts from plants used in the traditional medicine of North Africa countries. Farmacogenesia. 1995: 10. 150-153.

28. Bendjeddou $\mathbf{D}$, Lalaoui K, Satta D. Immunostimulating activity of the hot water soluble polysaccharide extract of Anacyclus pyrethrum, Alpinia galangal, and Citruluscolosysnthis. J Ethanopharmacol 2003. 88: 155160. 41. 